Universidade Federal de Santa Catarina

From the SelectedWorks of Sergio Da Silva

September, 2008

\title{
Foreign Exchange Intervention and Central Bank Independence: The Latin American Experience
}

Mauricio Nunes

Sergio Da Silva 


\title{
Foreign exchange intervention and central bank independence: the Latin American experience
}

\author{
Mauricio Nunes ${ }^{\mathrm{a}}$ and Sergio Da Silva ${ }^{\mathrm{b}}, *$ \\ ${ }^{a}$ Department of Economics, Federal University of Rio Grande Do Sul, Porto \\ Alegre, Brazil \\ ${ }^{\mathrm{b}}$ Department of Economics, Federal University of Santa Catarina, CSE, \\ Florianopolis, 88049-970 Brazil
}

Employing data from 13 Latin American countries, we find that greater central bank independence is associated with lesser intervention in the foreign exchange market, and also with leaning-against-the-wind intervention. We also find that the structural reforms that occurred in Latin America mostly in the 1990s helped to reduce the need for foreign exchange intervention.

\section{Introduction}

Central bank independence to conduct monetary policy has been related to low inflation rates with no consequences for economic growth (Grilli et al., 1991; Cukierman, 1992; Alesina and Summers, 1993; Eijffinger and Haan, 1996; Jacome, 2001; Jacome and Vasquez, 2005). Heightened independence can also be associated with lesser intervention in the foreign exchange market. Indeed a negative relationship between foreign exchange intervention and central bank independence has been found for 20 industrialized countries (Almekinders, 1995) in a study that employed both changes in currency reserves as proxies for intervention and the central bank independence index of Eijffinger and Schaling (1993). The negative relationship also holds for the variability of intervention and independence. (Foreign exchange intervention surveys include Sarno and Taylor (2001) and Taylor (2004)).
The relationship between foreign exchange intervention and central bank independence will be our concern in this article. We will taka data from Latin American countries and put forward an alternative methodology.

The usage of changes in reserves to proxy for intervention activity can be criticized on the basis that they are too noisy and that reserves can change for reasons having nothing to do with intervention. Rather than relying on net foreign reserves, here we will take the policy rule to track intervention.

$$
\ln \left(i_{t}^{T}\right)=\phi \ln \left(R_{t}-1\right)
$$

Here $i^{T}$ is the target to the nominal interest rate. Departures of the nominal exchange rate from its target are captured by the deviations of real exchange rate $R$ from its PPP value of one. Equation 1 can be justified on the basis that a central bank's main

*Corresponding author. E-mail: professorsergiodasilva@gmail.com 
concern in intervention activity is to counteract speculative nominal exchange rate changes.

The rest of the article is organized as follows. Section II will present data. Section III will analyse the data. Section IV will conclude.

\section{Data}

We consider 13 countries, namely Argentina, Bolivia, Brazil, Chile, Colombia, Costa Rica, Dominican Republic, Guatemala, Mexico, Paraguay, Peru, Uruguay and Venezuela, and take monthly data on nominal interest rates, nominal exchange rates and price levels over the period January 1990 to December 2003 (the only available) from the IMF's International Financial Statistics. The central bank (legal) independence index employed is that of Jacome and Vasquez (2005). This index takes into account not only economic and political sovereignty (as in Cukierman, 1992) but also financial sovereignty, responsibility, transparency and the role of the central bank as a lender in the last resort.

Table 1. Latin American central bank independence and reform

\begin{tabular}{lll}
\hline & Time period & CBII \\
\hline Group 1 & & 0.84 \\
ARG-1 & $1993-2003$ & \\
BOL-1 & $1996-2003$ & \\
CHI & $1990-2002$ & \\
COL-1 & $1993-2003$ & \\
MEX-1 & $1994-2003$ & 0.70 \\
PER-1 & $1994-2003$ & \\
Group 2 & & \\
CRC-1 & $1996-2003$ & \\
PAR-1 & $1996-2003$ & \\
URU-1 & $1996-2003$ & \\
VEN-1 & $1993-2003$ & \\
Group 3 & & \\
ARG-0 & $1990-1992$ & \\
BOL-0 & $1990-1995$ & \\
BRA & $1990-2003$ & \\
COL-0 & $1990-1992$ & \\
CRC-0 & $1990-1995$ & \\
GUA & $1990-2003$ & \\
DOM & $1990-2003$ & \\
MEX-0 & $1990-1993$ & \\
PAR-0 & $1990-1995$ & \\
PER-0 & $1990-1993$ & \\
URU-0 & $1990-1995$ & \\
VEN-0 & $1990-1992$ & \\
\hline SOI $-190 m e$ & & \\
\hline
\end{tabular}

Source: Jacome and Vasquez (2005).

Notes: Reform countries are indicated with either ' 0 ' (prereform subperiod) or ' 1 ' (post-reform subperiod). CBII is the central bank independence index.

\section{Analysis}

Latin American countries recently pursued more central bank independence through major reforms, most noticeably in Argentina (1992 and 2002), Bolivia (1995), Chile (1989), Colombia (1992), Costa Rica (1995), Mexico (1993), Paraguay (1995), Peru (1993), Uruguay (1995) and Venezuela (1992 and 2001). Table 1 shows the countries' central bank intervention index taking into account those reforms. Reform countries are indicated with either ' 0 ' (pre-reform subperiod) or ' 1 ' (post-reform subperiod). We assessed the relationship between central bank independence and intervention employing both individual country estimation (Table 2) and cross-country estimation through panel data (Table 3).

Policy rule (1) was used to proxy for intervention in individual country estimation. The intervention coefficients employed were obtained by individually estimating (via OLS) Equation 1 for every country (Table 2). In Table $2, \Delta$ is a series' first differences in natural $\log$ and $D$ is the deviation of the real exchange rate from the PPP value of one. Estimates in the regressions of Table 2 were backed by standard econometric treatment. To prevent spourious regressions, ADF and Phillips-Perron tests were employed in order to check for stationarity. We also run a CUSUM test to check for parameter stability. Moreover, whenever autocorrelation and heteroscedasticity in residuals were detected, they were fixed through Newey-West correction.

That leaning against the wind is the usual type of intervention can be seen in the negative sign of the deviations of the real exchange rate from its PPP value of one in the regressions for Argentina (1), Bolivia (1), Brazil, Chile, Colombia (0 and 1), Paraguay (1), Peru and Venezuela (0 and 1) (Table 2). The positive sign of the regressions in Table 2 refers to the countries with leaning-withthe-wind intervention.

Countries experiencing crises over the period were Argentina (2002), Colombia (1998-1999), Dominican Republic (2002-2003), Mexico (1995), Uruguay (2002) and Venezuela (1994-1995). For these countries, we considered banking crisis dummies. But these alone can lead to an omitted variable bias because the central bank reforms after the crises were usually part of broader structural reforms that included privatizations, trade reform and other structural macro policies (Jacome and Vasquez, 2005). To circumvent this bias, we considered the index of structural reform of the Inter-American Development Bank as an extra control variable (Lora, 2001; Lora and Panizza, 2002). 
Table 2. Individual country regressions using policy rule (1)

\begin{tabular}{|c|c|c|}
\hline$\Delta i^{T}=1_{(8.75)}^{3621^{*} \Delta D}$ & Adjusted $R^{2}=0.45$ & $\overline{(\mathrm{ARG}-0)}$ \\
\hline $\ln i^{T}=\underset{(-3.65)}{-0.18^{*}} \ln D$ & Adjusted $R^{2}=0.03$ & $(\mathrm{ARG}-1)$ \\
\hline $\ln i^{T}=\underset{(2.45)}{0.006^{*}}+\underset{(2.58)}{0.805^{*}} \ln D$ & Adjusted $R^{2}=0.24$ & $(\mathrm{BOL}-0)$ \\
\hline $\ln i^{T}=\underset{(-3.50)}{-0.050^{*}} \ln D$ & Adjusted $R^{2}=0.02$ & $(\mathrm{BOL}-1)$ \\
\hline $\ln i^{T}=\underset{(7.54)}{1.336^{*}}-\underset{(-2.73)}{0.0512^{*}} \ln D$ & Adjusted $R^{2}=0.03$ & (BRA) \\
\hline $\ln i^{T}=\underset{(11.24)}{1.456^{*}}-\underset{(-10.6)}{0.216^{*}} \ln D$ & Adjusted $R^{2}=0.33$ & $(\mathrm{CHI})$ \\
\hline$\Delta i^{T}=\underset{(2.72)}{0.02^{*}}+\underset{(2.29)}{0.048^{*}} \Delta D$ & Adjusted $R^{2}=0.14$ & $(\mathrm{COL}-0)$ \\
\hline $\ln i^{T}=\underset{(26.03)}{0.404^{*}}-\underset{(-13.42)}{0.238^{*}} \ln D$ & Adjusted $R^{2}=0.77$ & $(\mathrm{COL}-1)$ \\
\hline$\Delta i^{T}=\underset{(2.43)}{0.51^{*}} \Delta D$ & Adjusted $R^{2}=0.17$ & $(\mathrm{CRC}-0)$ \\
\hline $\ln i^{T}=-\underset{(-4.18)}{0.05^{*}} \ln D$ & Adjusted $R^{2}=0.13$ & $(\mathrm{CRC}-1)$ \\
\hline$\Delta i^{T}=\underset{(-6.43)}{0.38^{*}}+\underset{(9.12)}{0.155^{*}} \Delta D$ & Adjusted $R^{2}=0.46$ & $(\mathrm{DOM})$ \\
\hline$\Delta i^{T}=\underset{(6.52)}{0.116^{*}} \Delta D$ & Adjusted $R^{2}=0.06$ & $(\mathrm{GUA})$ \\
\hline $\ln i^{T}=\underset{(-3.35)}{1.44^{*}}+\underset{(3.84)}{0.675^{*}} \ln D$ & Adjusted $R^{2}=0.65$ & $(\mathrm{MEX}-0)$ \\
\hline $\ln i^{T}=\underset{(-8.62)}{1.22^{*}}+\underset{(9.78)}{0.599^{*}} \ln D$ & Adjusted $R^{2}=0.71$ & $(\mathrm{MEX}-1)$ \\
\hline $\ln i^{T}=\underset{(12.3)}{0.019^{*}} \ln D$ & Adjusted $R^{2}=0.005$ & $(\mathrm{PAR}-0)$ \\
\hline $\ln i^{T}=-\underset{(-3.54)}{1.33^{*}} \Delta D$ & Adjusted $R^{2}=0.71$ & $(\mathrm{PAR}-1)$ \\
\hline $\ln i^{T}=\underset{(3.67)}{0.807^{*}} \ln D$ & Adjusted $R^{2}=0.003$ & $(\mathrm{PER}-0)$ \\
\hline $\ln i^{T}=\underset{(4.75)}{0.435^{*}}-\underset{(-3.10)}{0.265^{*}} \ln D$ & Adjusted $R^{2}=0.19$ & (PER-1) \\
\hline$\Delta i^{T}=\underset{(6.80)}{1.443^{*}} \Delta D$ & Adjusted $R^{2}=0.41$ & (URU-0) \\
\hline$\Delta i^{T}=\underset{(3.43)}{0.369^{*}} \Delta D$ & Adjusted $R^{2}=0.03$ & (URU-1) \\
\hline $\ln i^{T}=\underset{(-2.04)}{2.43^{*}}-\underset{(2.37)}{0.271^{*}} \ln D$ & Adjusted $R^{2}=0.28$ & $(\mathrm{VEN}-0)$ \\
\hline $\ln i^{T}=\underset{(-26.52)}{-0.049^{*}} \ln D$ & Adjusted $R^{2}=0.07$ & (VEN-1) \\
\hline
\end{tabular}

Notes: Figures in brackets show the $t$-statistic and $D$ is the deviation of the real exchange rate from the PPP value of one.

*Means significance at 5\%.

Table 3. Panel regressions using FGLS

\begin{tabular}{|c|c|c|c|c|c|c|c|c|}
\hline Regression & [1] & & [2] & & [3] & & [4] & \\
\hline Constant & $0.0008^{*}$ & $(66.82)$ & $0.000^{*}$ & $(67.07)$ & $0.0008^{*}$ & $(58.03)$ & $0.0008^{*}$ & $(51.39)$ \\
\hline $\begin{array}{l}\text { Central bank } \\
\text { independence index }\end{array}$ & $-0.199^{*}$ & $(-2.53)$ & $-0.176^{*}$ & $(-2.03)$ & $-20.05^{*}$ & $(-2.49)$ & $-20.06^{*}$ & $(-2.48)$ \\
\hline Structural reform index & & & $2.20 \mathrm{E}^{-0.7 * *}$ & $(-1.76)$ & & & $0.02^{* *}$ & $(-2.52)$ \\
\hline Dummy for banking crisis & & & & & 0.03 & $(-0.75)$ & 0.03 & $(-0.75)$ \\
\hline$R^{2}$ & & 0.033 & & 0.79 & & 0.032 & & 0.030 \\
\hline Observations & & 2.184 & & 2.184 & & 2.184 & & 2.184 \\
\hline Number of countries & & 13 & & 13 & & 13 & & 13 \\
\hline$\rho$ & & 0.98 & & 0.98 & & 0.98 & & 0.98 \\
\hline
\end{tabular}

Notes: Figures in brackets show the $t$-statistic.

*Means significance at $5 \%$ and ${ }^{* *}$ means significance at $10 \%$.

The four panels in Table 3 show a negative relationship between the foreign exchange intervention coefficient and the central bank independence index over the period 1990 to 2003 . The coefficients were estimated by feasible generalized least squares (FGLS) and robust coefficient covariances (White robust covariances), allowing for heteroscedasticity across countries and computing White-type robust 
SEs, together with an AR(1) autocorrelation structure and with a $\rho$ coefficient common to all countries.

Regression [1] considered only the central bank index, regression [2] added the structural reform index and regression [3] added the banking crisis dummy. Regression [4] took all those into account. Apart from the dummy for banking crisis, Table 3 shows that the variables were related at a significance level of up $10 \%$. Thus, the proposition that increased central bank independence can be associated with lesser intervention in foreign exchange markets holds for Latin America. Also, the structural reforms helped to reduce the need for foreign exchange intervention. The banking crises did not matter for intervention, however. Indeed the $R^{2}$ in regression [3] suggests that nearly $79 \%$ of the changes occurring in the intervention coefficient can be explained solely by the independence and structural reform indices.

\section{Conclusion}

The experience of 13 Latin American countries suggests that greater central bank independence can be associated with both (1) lesser intervention in the foreign exchange market and (2) leaningagainst-the-wind intervention. These findings are in accordance with previous ones for industrialized countries. However, such studies relied on OLS cross-country regressions and foreign reserves as a proxy for intervention. Rather than using reserves, we assessed the relationship between central bank independence and intervention employing both individual-country estimation (via a policy rule) and cross-country estimation through panel data. Incidentally, we also found that the structural reforms that occurred in Latin America helped to reduce the need for foreign exchange intervention.

\section{Acknowledgements}

S. Da Silva and M. Nunes acknowledge financial support from the Brazilian agencies $\mathrm{CNPq}$ and CAPES-Procad.

\section{References}

Alesina, A. and Summers, L. H. (1993) Central bank independence and macroeconomic performance: some comparative evidence, Journal of Money, Credit, and Banking, 25, 151-62.

Almekinders, G. J. (1995) Foreign Exchange Intervention: Theory and Evidence, Edward Elgar, Hants.

Cukierman, A. (1992) Central Bank Strategy, Credibility, and Independence: Theory and Evidence, The MIT Press, Cambridge, MA.

Eijffinger, S. C. W. and Haan, J. (1996) The political economy of central banking, Princeton Special Papers in International Economics, No. 19.

Eijffinger, S. C. W. and Schaling, E. (1993) Central bank independence in twelve industrial countries, Banca Nazionale del Lavoro Quarterly Review, 184, 1-41.

Grilli, V., Masciandaro, D. and Tabellini, G. (1991) Political and monetary institutions and public finance policies in the industrial countries, Economic Policy, 13, 341-92.

Jacome, L. I. (2001) Legal central bank independence and inflation in Latin America during the 1990s, IMF Working Papers No. 212.

Jacome, L. I. and Vasquez, F. (2005) Any link between legal central bank independence and inflation? Evidence from Latin America and the Caribbean, IMF Working Papers No. 75.

Lora, E. (2001) Structural reforms in Latin America: what has been reformed and how to measure it, InterAmerican Development Bank Working Paper No. 466.

Lora, E. and Panizza, U. (2002) Structural reforms in Latin America under scrutiny, Inter-American Development Bank Working Papers, No. 470.

Sarno, L. and Taylor, M. P. (2001) Official intervention in the foreign exchange market: Is it effective and, if so, how does it work? Journal of Economic Literature, 39, 839-68.

Taylor, M. P. (2004) Is official exchange rate intervention effective? Economica, 71, 1-11. 